\title{
Vliv intervenčního programu poweryoga na změny úrovně statické rovnováhy a složení těla - BMI
}

\section{Effect of the poweryoga intervention programme on changes in the levels of static balance and body composition - BMI}

\author{
Kateřina Feitová ${ }^{1}$, Viléma Novotná ${ }^{2}$ \\ ${ }^{1}$ Př́rodovědecká fakulta Univerzity Karlovy, Praha \\ ${ }^{2}$ Fakulta tělesné výchovy a sportu Univerzity Karlovy, Praha
}

\begin{abstract}
Abstrakt:
V př́spěvku jsou uvedeny výsledky pilotního výzkumu měření změn úrovně statické rovnováhy a složení těla - BMI (body mass index) vlivem působení programu poweryogy. Tříměsiční intervenční program byl realizován s experimentální skupinou studentek Př́rodovědecké fakulty UK v Praze. Měření úrovně statické rovnováhy proběhlo pomocí testu: výdrž ve stoji na jedné noze s vyloučením zrakové kontroly, hodnoty BMI byly získány výpočtem poměru výšky a hmotnosti jednotlivých probandek. Po absolvování intervenčního programu došlo i pres krátkodobé působení k pozitivním změnám v úrovni statické rovnováhy, vzhledem k malému počtu testovaných osob na nízké hladině významnosti. Změny BMI se ukázaly zanedbatelné z dìvodu krátké doby trvání a jednostrannosti intervence. Výsledky budou použity k úpravě pohybového obsahu intervenčního programu poweryogy v rámci komplexního výzkumu účinnosti pohybového programu a jako argumenty podpory prínosu této pohybové aktivity pro vysokoškolské studentky.
\end{abstract}

\begin{abstract}
:
This contribution presents the results of a pilot study measuring changes in the levels of static balance and body composition (BMI) brought about by practising the poweryoga programme. The 3-month intervention programme was applied to an experimental group of female students at the Faculty of Science of Charles University in Prague. The test to ascertain the static balance level measured the time for which the subjects were able to stand on one leg without visual control; the BMI data were obtained from the subjects height-to-weight ratios. Although practised for a short-time only, the intervention programme resulted in positive changes in the static balance level (at a low level of significance due to the small number of subjects involved). BMI changes appeared to be negligible due to the short time and one-sidedness of the intervention. The results will be used to modify the motion content of the poweryoga intervention programme within a comprehensive study of the efficiency of the motion programme and in support of usefulness of this motion activity for female university students.
\end{abstract}

Klíčová slova: $\quad$ Pohybový program, poweryoga, statická rovnováha, body mass index (BMI). Key words: $\quad$ Motion programme, poweryoga, static balance, body mass index (BMI).

Tento př́spěvek vznikl v rámci projektu Specifického vysokoškolského výzkumu 2012-265 603 a Výzkumného záměru UK FTVS, MSM 0021620864.

\section{ÚVOD}

I přes odbornou argumentaci o pozitivním významu pohybu pro život člověka nejsou ve větší míře ani studentky vysokých škol schopny začlenit pohybovou aktivitu do svého běžného životního stylu. Přesto právě u této skupiny populace očekáváme pochopení důležitosti propojení intelektuální a fyzické zdatnosti ve vztahu k rovnoměrnému harmonickému rozvoji osobnosti. Tuto situaci se snažíme ovlivnit nabídkou vhodných programů fitness, odpovídajících potřebám a očekávání studentek. Jedním z nich je i pohybový program poweryoga. Cílem pohybového tréninku studentek není zvyšování sportovní výkon- 
nosti, ale především kompenzace nedostatku pohybu v současném životním stylu a podpora zdravotní prevence cíleně směrované na předcházení somatických a psychických potíží. Zvládnutí studijní zátěže je možné podpořit vhodným pohybovým programem zaměřeným na zlepšování koncentrace, vyrovnávání svalových dysbalancí, ovlivňování složení těla a na zvyšování spokojenosti studentek se svým způsobem života. Do předmětu tělesné výchovy - poweryoga se zapisují především studentky, které upřednostňují kolektivní formy gymnastických cvičení, částečně spojených s hudbou.

Pohybový program je založený na principech cvičení Reebok Flexible Strenght, Power yoga Baron Baptiste a Reebok yoga. Poweryoga sice využívá pozic - ásan klasické jógy, ale upravuje je do systému silových cvičení dynamického charakteru. Typickým znakem cvičení jsou kratší výdrže a plynulé procházení pozicemi, často silově velmi náročnými. Při cvičení jsou využívána pravidla a principy metod strečinku, mobilizačních cvičení a rehabilitace. Za hlavní cíl je deklarováno zlepšení fyzické i psychické kondice, rozvoj síly a flexibility. Dále pak vyrovnávání svalových dysbalancí, tvarování problémových partií, úprava hmotnosti, uvolnění mysli i těla a celková relaxace. Poweryoga je vytržena z uceleného systému tradiční jógy. Chybí zde náročné dechové a mentální techniky. Tato nová forma cvičení je však přístupná širokému spektru cvičenců (Krejčík 2005). Jógová cvičení vedou k vnímání vnitřních pocitů při pohybu (napětí a uvolnění) a k poznání svých reakcí. Nenutí cvičenky k neustálému srovnávání sebe s druhými. Správné provádění jógových cvičení je spojeno s respektováním individuálních dispozic. Jóga vnáši do našeho školního vzdělávání opomíjenou dimenzi - sebepoznání (Krejčí 1995).

Poweryoga je často spojována se zdokonalováním koordinačních schopností cvičenců (Howe 2011; Thomley 2011). Jednou ze základních koordinačních schopností je rovnováha. Je to schopnost zachovat $\mathrm{v}$ průběhu pohybové činnosti rovnováhu těla, př́ípadně ji znovu obnovit, pokud dojde $\mathrm{k}$ jejímu narušení (Doležajová; Lednický 2002). Dobře rozvinuté koordinační schopnosti ovlivňují rychlost motorického učení, a tím i přesnost osvojení si techniky (Strešková 2004). Právě technika provedení jednotlivých jógových ásan je určující pro zvládnutí celých vinyas - jógových sestav, které jsou základem cvičebních jednotek poweryogy.

Cílem příspěvku je vyhodnocení výsledků pilotního výzkumu měření změn úrovně statické rovnováhy v testu rovnovážných schopností a posouzení výsledných parametrů složení těla - BMI u vybrané skupiny studentek Př́rodovědecké fakulty UK v Praze, jako jedné z částí ověřování účinnosti intervenčního programu poweryogy.

\section{METODIKA}

Heuristický experiment probíhal ve školním prostředí, na Přírodovědecké fakultě UK v Praze. Intervenční program poweryogy byl veden formou skupinového cvičení a byl aplikován ve studijním plánu hodin předmětu tělesná výchova na VŠ. Z důvodu omezených možností výběru respondentek pro pilotní výzkum se měřenými osobami staly studentky přihlášené do daného předmětu. Jednalo se tedy o záměrný výběr testovaných osob. Řídili jsme se proto pravidly kvaziexperimentálního plánu studie (Thomas; Nelson 1996). Př́i realizaci byl sledován vliv krátkodobé intervence programu na změny úrovně statické rovnováhy a na korekci parametru složení těla - BMI. Pro výzkum byla použita experimentální metoda empirického výzkumu (Blahuš 1996). Jednalo se o longitudinální sledování meziskupinových vztahů mezi vstupní proměnnou v podobě aplikace programu poweryogy a výstupní proměnnou, kterou tvořily výsledky vybraného testu rovnovážných schopností a stanovení BMI. Záměrem šetření bylo zjistit, zda již tř́měsíční vliv poweryogy je znatelný v porovnání s kontrolní skupinou. V intervenčním programu aplikovaném jedenkrát týdně po dobu devadesáti minut byly zařazeny základní pohybové sekvence cvičebního programu poweryogy. Vycházeli jsme ze studie jednoho ze zakladatelů poweryogy B. Baptisty (1988). Protože jógové ásany jsou rovnovážnými polohami a uvědomělá výdrž v těchto polohách je balančním cvičením propojeným se statickým posilováním, předpokládali jsme i pozitivní ovlivnění rovnováhy a hodnot vyjadřujících stabilitu postoje. Měření statické rovnováhy u experimentální i kontrolní skupiny bylo provedeno na začátku a na konci testovacího období.

Součástí pilotního výzkumu bylo i měření BMI u obou skupin studentek před zahájením intervence a po jejím ukončení. Celková hmotnost těla je tvořena jednotlivými složkami (např. vodou, minerál- 
ními látkami, proteiny, tukem). U zdravých dospělých jedinců je poměr těchto složek téměř konstantní, avšak platí, že ke změnám dochází nejen v závislosti na věku a pohlaví, ale také úpravou určitého způsobu života (např. stravovací návyky, pohybová aktivita). Proto do měřeného souboru byli záměrně vybráni studenti stejného pohlaví a srovnatelného věku. Vzhledem $\mathrm{k}$ tomu, že charakter obou měřených proměnných byl intervalový, porovnávali jsme korelační koeficienty pretestu a posttestu. Při porovnávání meziskupinových rozdílů jsme brali v úvahu diagnostickou chybu měření, vyjádřenou ve výsledcích intervalem. Diagnostická chyba měření vycházela ze směrodatné odchylky naměřených výsledků a umožňovala je statisticky porovnat.

\section{Výzkumný soubor}

V pilotním měření bylo sledováno 20 studentek 2 . ročníku PřF UK v Praze.

1. Skupina E: Experimentální skupina (10 studentek ve věku 20-21 let), která se po dobu 12 týdnů věnovala programu poweryogy.

2. Skupina K: Kontrolní skupina (10 studentek ve věku 20-21 let), která se nevěnovala žádnému řízenému pohybovému programu.

\section{Metody měření}

Testování úrovně rovnovážných schopností.

Testování bylo zpracováno podle Blahuše, Měkoty (1983), Neumana (2003) a Streškové (2010). Statickou rovnováhou se rozumí schopnost udržet stálou polohu těla. Test rovnovážných schopností byl prováděn na lavičce ve stoji na jedné noze s vyloučením zrakové kontroly (pokrčená noha, špička v úrovni kolenního kloubu bez opory o stojnou nohu, ruce $\mathrm{v}$ bok). Test byl ukončen porušením postoje nebo oddálením paží či nohy od těla, při otevření očí, při doteku země jinou částí těla nebo pokud došlo k úklonu trupu většímu než 45 stupňů. Záznam byl proveden v sekundách $\mathrm{s}$ přesností na $0,1 \mathrm{~s}$, spolehlivost $\mathrm{r}_{\text {stab }}=0,72$.

Byla měřena hodnota rozdílu časů výdrže na pravé a levé noze, dále statisticky vyhodnocena v rámci obou celých skupin (deset diskrétních hodnot rozdílu). Protože měření bylo pouze pilotní a celý soubor měl méně než dvacet hodnot, odhad střední hodnoty byl proveden pomocí mediánu, který byl určen jako aritmetický průměr dvou prostředních hodnot v seřazeném desetihodnotovém seznamu. Rozpětí souboru dat bylo vypočítáno jako rozdíl nejmenšího a největšího času v celém souboru. Z rozpětí byly pak za užití tabelovaných koeficientů $\mathrm{k}_{10}$, resp. $\mathrm{K}_{10}$ (platných pro soubor deseti hodnot a pro koeficient $\mathrm{K}_{\mathrm{n}}$ také pro hladinu významnosti 0,05 , to jest koeficient spolehlivosti 0,95 ) vypočítány hodnoty směrodatné odchylky a meze opakovatelnosti neboli poloměru intervalu spolehlivosti okolo mediánu jako střední hodnoty.

Posouzení tělesného parametru - BMI.

Obezita představuje pro populaci velké zdravotní riziko. Zvyšuje nebezpečí vzniku kardiovaskulárních onemocnění, poškozuje klouby, zvyšuje pravděpodobnost onemocnění cukrovkou a je rizikovým faktorem mnoha dalších nemocí. V moderní společnosti se obezita stává novou epidemií a řadí se k největším problémům medicíny. Jednoduchou součástí prevence obezity je pravidelná kontrola hmotnosti a výpočet BMI (poměr mezi výškou a hmotností těla) pomocí jednoduchého vztahu a porovnání výsledku s normálními hodnotami (Tab. 1).

$$
B M I=\frac{h m o t n o s t(k g)}{[v y ́ s ̌ k a(m)]^{2}}
$$

Existuje celá řada dalších laboratorních vyšetření složení těla (např. metody podvodních testů, ultrazvuk, kaliperace), které ve školní praxi lze jen těžko aplikovat. Proto byl pro pilotní výzkum zvolen způsob měření podle Fialové (2006). Vzhledem k tomu, že se tělesná hmotnost i výška během dne mění, bylo kontrolní měření u obou skupin prováděno vždy na stejné váze (měřidle) a ve stejný čas. 
Tab. 1: Slovní vyjádření indexu. Hodnocení obezity podle hmotnostního indexu (Pařízková 1998)

\begin{tabular}{|c|c|c|}
\hline Klasifikace & BMI & Riziko vzniku onemocnění \\
\hline podváha & menší než 18,5 & malé \\
\hline normální hmotnost & $18,5-24,9$ & průměrné \\
\hline nadváha & $25,0-29,9$ & mírně zvýšené \\
\hline obezita 1. stupně & $30,0-34,9$ & středně zvýšené \\
\hline obezita 2. stupně & $35,0-39,9$ & dosti zvýšené \\
\hline obezita 3. stupně & více než 40,0 & velmi zvýšené \\
\hline
\end{tabular}

\section{VÝSLEDKY A DISKUSE}

Pilotní měření statické rovnováhy bylo realizováno na záměrně vybraných studentkách na začátku a na konci 12týdenního cyklu, během kterého byl aplikován pohybový program. V prvním souboru (E) vyšel statistický výsledek 00:18,0 \pm 00:17,5 pro pravou a 00:16,4 \pm 00:07,8 pro levou nohu. V druhém souboru (K) 00:28,7 \pm 00:12,9 pro pravou a 00:20,5 \pm 00:09,6 pro levou nohu. To znamená, že lze na základě sebraných dat garantovat s $95 \%$ pravděpodobností, že pokud by se měřil čas u kterékoliv vybraného souboru studentek znovu, tak by jeho konkrétní délka padla do intervalu vymezeného mezí opakovatelnosti na obě strany od mediánu. Výsledky měření hodnoty rozdílu časů výdrže na pravé a levé noze jsou prezentovány v Tab. 2 a v Tab. 3.

Tab. 2: Statistické zpracování rozdílu hodnot časů výdrže na pravé a levé noze - experimentální skupina

\begin{tabular}{|c|c|c|c|c|c|c|}
\hline \multirow[b]{2}{*}{ Proband č. } & \multicolumn{2}{|c|}{$\begin{array}{l}\text { Měření č. } 1 \text { - pretest } \\
\text { (začátek } 12 \text { týdenního cyklu) }\end{array}$} & \multicolumn{2}{|c|}{$\begin{array}{l}\text { Měření č.2 - posttest } \\
\text { (konec } 12 \text { týdenního cyklu) }\end{array}$} & \multicolumn{2}{|c|}{$\begin{array}{l}\text { Rozdíl } \\
\text { (mezi 1. a 2. měřením) }\end{array}$} \\
\hline & Výdrž pravá (min) & Výdrž levá (min) & Výdrž pravá (min) & Výdrž levá (min) & Rozdíl pravá & Rozdíl levá \\
\hline 1. & \begin{tabular}{|r|}
$00: 14,2$ \\
\end{tabular} & $01: 40,0$ & $00: 32,2$ & $01: 22,0$ & $\begin{array}{r}00: 18,0 \\
\end{array}$ & $00: 18,0$ \\
\hline 2. & $01: 42,0$ & $00: 20,1$ & $02: 59,0$ & $00: 30,2$ & $01: 17,0$ & $00: 10,0$ \\
\hline 3. & $00: 04,0$ & $00: 32,5$ & $00: 22,0$ & $00: 46,3$ & $00: 18,0$ & $00: 13,8$ \\
\hline 4. & $01: 50,0$ & $00: 32,3$ & $01: 55,0$ & $01: 07,0$ & $00: 05,0$ & $00: 34,7$ \\
\hline 5. & $00: 18,0$ & $00: 18,5$ & $00: 03,2$ & $00: 53,2$ & $00: 14,8$ & $00: 34,8$ \\
\hline 6. & $00: 08,3$ & $00: 53,2$ & $00: 14,2$ & $00: 38,5$ & $00: 05,9$ & $00: 14,7$ \\
\hline 7. & $00: 17,4$ & $00: 13,5$ & $00: 18,2$ & $00: 14,5$ & $00: 00,8$ & $00: 01,0$ \\
\hline 8. & $00: 52,1$ & 00:20,1 & $01: 28,0$ & $00: 28,3$ & $00: 35,9$ & $00: 08,2$ \\
\hline 9. & $01: 22,0$ & $00: 55,0$ & $01: 40,0$ & $01: 20,2$ & $00: 18,0$ & $00: 25,2$ \\
\hline 10. & $00: 56,0$ & $01: 23,0$ & $01: 25,0$ & $01: 54,0$ & $00: 29,0$ & $00: 31,0$ \\
\hline Průměr & $00: 46,4$ & $00: 42,8$ & $01: 05,7$ & $00: 55,4$ & $00: 22,2$ & $00: 19,1$ \\
\hline Medián & $00: 35,1$ & $00: 32,4$ & $00: 58,6$ & $00: 49,7$ & $00: 18,0$ & $00: 16,4$ \\
\hline Rozpětí & $01: 46,0$ & $01: 26,5$ & $02: 55,8$ & $01: 39,5$ & $01: 16,2$ & $00: 33,8$ \\
\hline Směrodatná odchylka $(\mathrm{kn} 0,325)$ & $00: 34,5$ & $00: 28,1$ & $00: 57,1$ & $00: 32,3$ & $00: 24,8$ & $00: 11,0$ \\
\hline Relativní směrodatná odchylka & 0,983 & 0,868 & 0,975 & 0,650 & 1,376 & 0,670 \\
\hline Interval spolehlivosti $(\mathrm{Kn} 0,23)$ & $00: 24,4$ & $00: 19,9$ & $00: 40,4$ & $00: 22,9$ & $00: 17,5$ & 00:07,8 \\
\hline \multicolumn{5}{|l|}{ Statistický výsledek s mediánem } & $00: 18,0+/-00: 17,5$ & $00: 16,4+/-00: 07,8$ \\
\hline \multicolumn{5}{|l|}{ Statistický výsledek s průměrem } & $00: 22,2+/-00: 17,5$ & $00: 19,1+/-00: 07,8$ \\
\hline
\end{tabular}

Tab. 3: Statistické zpracování rozdílu hodnot časů výdrže na pravé a levé noze - kontrolní skupina

\begin{tabular}{|c|c|c|c|c|c|c|}
\hline \multirow[b]{2}{*}{ Proband č. } & \multicolumn{2}{|c|}{\begin{tabular}{|l} 
Měření č. 1 - pretest \\
(začátek 12 týdenního cyklu)
\end{tabular}} & \multicolumn{2}{|c|}{$\begin{array}{l}\text { Měření č.2 - posttest } \\
\text { (konec } 12 \text { týdenního cyklu) }\end{array}$} & \multicolumn{2}{|c|}{$\begin{array}{l}\text { Rozdíl } \\
\text { (mezi 1. a 2. měřením) }\end{array}$} \\
\hline & Výdrž pravá (min) & Výdrž levá (min) & Výdrž pravá (min) & Výdrž levá (min) & Rozdil pravá & Rozdíl levá \\
\hline 1. & \begin{tabular}{|r|}
$00: 17,2$ \\
\end{tabular} & \begin{tabular}{|r|}
$01: 20,0$ \\
\end{tabular} & \begin{tabular}{|r|}
$00: 58,3$ \\
\end{tabular} & $01: 57,0$ & \begin{tabular}{|r|}
$00: 41,1$ \\
\end{tabular} & $00: 37,0$ \\
\hline 2. & $00: 17,4$ & 01:48,0 & $00: 45,0$ & 02:00,0 & $00: 27,6$ & $00: 12,0$ \\
\hline 3. & $01: 00,0$ & 02:35,0 & $01: 45,0$ & $02: 40,0$ & $00: 45,0$ & $00: 05,0$ \\
\hline 4. & $00: 17,0$ & $00: 14,5$ & $00: 33,2$ & $00: 22,1$ & $00: 16,2$ & $00: 07,6$ \\
\hline 5. & $00: 56,0$ & $00: 25,5$ & $01: 53,0$ & $00: 55,0$ & $00: 57,0$ & $00: 29,5$ \\
\hline 6. & $00: 34,2$ & $01: 11,0$ & $01: 04,0$ & $00: 42,0$ & $00: 29,8$ & $00: 29,0$ \\
\hline 7. & $00: 06,0$ & $00: 05,4$ & $00: 06,7$ & $00: 05,0$ & $00: 00,7$ & $00: 00,4$ \\
\hline 8. & $01: 32,0$ & $01: 25,0$ & $01: 45,2$ & $02: 07,0$ & $00: 13,2$ & $00: 42,0$ \\
\hline 9. & $01: 25,0$ & $01: 54,0$ & $01: 43,0$ & $01: 56,0$ & $00: 18,0$ & $00: 02,0$ \\
\hline 10. & $00: 54,0$ & $00: 32,0$ & $01: 32,0$ & $01: 10,0$ & $00: 38,0$ & $00: 38,0$ \\
\hline Průměr & $00: 43,9$ & $01: 09,0$ & $01: 12,5$ & $01: 23,4$ & $00: 28,7$ & $00: 20,3$ \\
\hline Medián & $00: 44,1$ & $01: 15,5$ & $01: 18,0$ & $01: 33,0$ & $00: 28,7$ & $00: 20,5$ \\
\hline Rozpětí & $01: 26,0$ & $02: 29,6$ & $01: 46,3$ & $02: 35,0$ & $00: 56,3$ & $00: 41,6$ \\
\hline Směrodatná odchylka $(\mathrm{kn} 0,325)$ & $00: 27,9$ & $00: 48,6$ & $00: 34,5$ & $00: 50,4$ & $00: 18,3$ & $00: 13,5$ \\
\hline Relativní směrodatná odchylka & 0,634 & 0,644 & 0,443 & 0,542 & 0,637 & 0,660 \\
\hline Interval spolehlivosti $(\mathrm{Kn} 0,23)$ & $00: 19,8$ & $00: 34,4$ & $00: 24,4$ & $00: 35,6$ & $00: 12,9$ & $00: 09,6$ \\
\hline \multicolumn{5}{|l|}{ Statistický výsledek s mediánem } & $00: 28,7+/-00: 12,9$ & $00: 20,5+/-00: 09,6$ \\
\hline \multicolumn{5}{|l|}{ Statistický výsledek s průměrem } & $00: 28,7+/-00: 12,9$ & $00: 20,3+/-00: 09,6$ \\
\hline
\end{tabular}


Analogickým zpơsobem byly vyhodnoceny i absolutní časy výdrže pro každé měření, celkem čtyři hodnoty pro každý soubor. $V$ experimentální skupině vycházel pro první měření čas 00:35,0 \pm 00:24,4 u pravé, 00:32,4 \pm 00:19,9 u levé a pro druhé měření čas 00:58,6 \pm 00:40,4 u pravé a 00:49,8 \pm 00:22,9 u levé nohy. U kontrolní skupiny byl čas pro první měření 00:44,1 \pm 00:19,8 u pravé a 01:15,5 \pm 00:34,4 u levé nohy. V druhém měření pak 01:18,0 \pm 00:24,4 pro pravou a 01:33,0 \pm 00:35,6 pro levou nohu. Provedený postup statistického zpracování předložených dat byl uskutečněn bez předchozí selekce dat prostřednictvím testu na odlehlé hodnoty, protože jak ukazují hodnoty směrodatných, respektive relativních směrodatných odchylek, jednotlivé hodnoty jsou značně rozházené. Výsledky měření absolutních časů výdrže na pravé a na levé noze jsou uvedeny v Tab. 4 a v Tab. 5.

Tab. 4: Statistické zpracování absolutních časů výdrže na pravé a levé noze - experimentální skupina

\begin{tabular}{|c|c|c|c|c|}
\hline \multirow[b]{2}{*}{ Proband č. } & \multicolumn{2}{|c|}{$\begin{array}{l}\text { Měření č. } 1 \text { - pretest } \\
\text { (začátek } 12 \text { týdenního cyklu) }\end{array}$} & \multicolumn{2}{|c|}{$\begin{array}{l}\text { Měření č.2 - posttest } \\
\text { (konec } 12 \text { týdenního cyklu) }\end{array}$} \\
\hline & Výdrž pravá (min) & Výdrž levá (min) & Výdrž pravá (min) & Výdrž levá (min) \\
\hline 1. & $00: 14,2$ & \begin{tabular}{|r|}
$01: 40,0$ \\
\end{tabular} & $00: 32,2$ & \begin{tabular}{|r|}
$01: 22,0$ \\
\end{tabular} \\
\hline 2. & $01: 42,0$ & $00: 20,1$ & $02: 59,0$ & $00: 30,2$ \\
\hline 3. & $00: 04,0$ & $00: 32,5$ & $00: 22,0$ & $00: 46,3$ \\
\hline 4. & $01: 50,0$ & $00: 32,3$ & $01: 55,0$ & 01:07,0 \\
\hline 5. & $00: 18,0$ & $00: 18,5$ & $00: 03,2$ & $00: 53,2$ \\
\hline 6. & $00: 08,3$ & $00: 53,2$ & $00: 14,2$ & $00: 38,5$ \\
\hline 7. & $00: 17,4$ & $00: 13,5$ & $00: 18,2$ & $00: 14,5$ \\
\hline 8. & $00: 52,1$ & $00: 20,1$ & $01: 28,0$ & $00: 28,3$ \\
\hline 9. & $01: 22,0$ & $00: 55,0$ & $01: 40,0$ & $01: 20,2$ \\
\hline 10. & $00: 56,0$ & $01: 23,0$ & $01: 25,0$ & $01: 54,0$ \\
\hline Průměr & $00: 46,4$ & $00: 42,8$ & 01:05,7 & $00: 55,4$ \\
\hline Medián & $00: 35,0$ & $00: 32,4$ & $00: 58,6$ & $00: 49,8$ \\
\hline Rozptyl & $01: 46,0$ & $01: 26,5$ & $02: 55,8$ & $01: 39,5$ \\
\hline Směrodatná odchylka (kn 0,325) & $00: 34,5$ & $00: 28,1$ & $00: 57,1$ & $00: 32,3$ \\
\hline Relativní směrodatná odchylka & 0,983 & 0,868 & 0,975 & 0,650 \\
\hline Interval spolehlivosti $(\mathrm{Kn} 0,23)$ & $00: 24,4$ & $00: 19,9$ & $00: 40,4$ & $00: 22,9$ \\
\hline Statistický výsledek s mediánem & $00: 35,0+/-00: 24,4$ & $00: 32,4+/-00: 19,9$ & $00: 58,6+/-00: 40,4$ & $00: 49,8+/-00: 22,9$ \\
\hline Statistický výsledek s průměrem & $00: 46,4+/-00: 24,4$ & $00: 42,8+/-00: 19,9$ & $01: 05,7+/-00: 40,4$ & $00: 55,4+/-00: 22,9$ \\
\hline
\end{tabular}

Tab. 5: Statistické zpracování absolutních časů výdrže na pravé a levé noze - kontrolní skupina

\begin{tabular}{|c|c|c|c|c|}
\hline \multirow[b]{2}{*}{ Proband č. } & \multicolumn{2}{|c|}{$\begin{array}{l}\text { Měření č. } 1 \text { - pretest } \\
\text { (začátek } 12 \text { týdenního cyklu) }\end{array}$} & \multicolumn{2}{|c|}{$\begin{array}{l}\text { Měření č.2 - posttest } \\
\text { (konec } 12 \text { týdenního cyklu) }\end{array}$} \\
\hline & Výdrž pravá (min) & Výdrž levá (min) & Výdrž pravá (min) & Výdrž levá (min) \\
\hline 1. & $00: 17,2$ & \begin{tabular}{|r|}
$01: 20,0$ \\
\end{tabular} & \begin{tabular}{|r|}
$00: 58,3$ \\
\end{tabular} & $\begin{array}{r}01: 57,0 \\
\end{array}$ \\
\hline 2. & $00: 17,4$ & $01: 48,0$ & $00: 45,0$ & $02: 00,0$ \\
\hline 3. & $01: 00,0$ & $02: 35,0$ & $01: 45,0$ & $02: 40,0$ \\
\hline 4. & $00: 17,0$ & $00: 14,5$ & $00: 33,2$ & $00: 22,1$ \\
\hline 5. & $00: 56,0$ & $00: 25,5$ & $01: 53,0$ & $00: 55,0$ \\
\hline 6. & $00: 34,2$ & $01: 11,0$ & 01:04,0 & $00: 42,0$ \\
\hline 7. & $00: 06,0$ & $00: 05,4$ & $00: 06,7$ & $00: 05,0$ \\
\hline 8. & $01: 32,0$ & $01: 25,0$ & $01: 45,2$ & $02: 07,0$ \\
\hline 9. & $01: 25,0$ & $01: 54,0$ & $01: 43,0$ & $01: 56,0$ \\
\hline 10. & $00: 54,0$ & $00: 32,0$ & $01: 32,0$ & $01: 10,0$ \\
\hline Průměr & $00: 43,9$ & 01:09,0 & $01: 12,5$ & $01: 23,4$ \\
\hline Medián & $00: 44,1$ & $01: 15,5$ & $01: 18,0$ & $01: 33,0$ \\
\hline Rozptyl & $01: 26,0$ & $02: 29,6$ & $01: 46,3$ & $02: 35,0$ \\
\hline Směrodatná odchylka $(\mathrm{kn} 0,325)$ & $00: 27,9$ & $00: 48,6$ & $00: 34,5$ & $00: 50,4$ \\
\hline Relativní směrodatná odchylka & 0,634 & 0,644 & 0,443 & 0,542 \\
\hline Interval spolehlivosti $(\mathrm{Kn} 0,23)$ & $00: 19,8$ & $00: 34,4$ & $00: 24,4$ & $00: 35,6$ \\
\hline Statistický výsledek s mediánem & $00: 44,1+/-00: 19,8$ & $01: 15,5+/-00: 34,4$ & $01: 18,0+/-00: 24,4$ & $01: 33,0+/-00: 35,6$ \\
\hline Statistický výsledek s průměrem & $00: 43,9+/-00: 19,8$ & $01: 09,0+/-00: 34,4$ & $01: 12,5+/-00: 24,4$ & $01: 23,4+/-00: 35,6$ \\
\hline
\end{tabular}

Vzhledem k tomu, že počet měřených osob pro zjištění hodnot statické rovnováhy byl velmi malý (pilotní měření), byla i hladina významnosti nízká. Výsledky měření ukázaly velkou rozdílnost mezi jednotlivými testovanými studentkami. Přesto jsme mohli pozorovat tendenci ke zlepšení na konci testovacího období, tedy po aplikaci pohybového programu. Byl potvrzen i rozdíl mezi testovanými studentkami skupiny $\mathrm{E}$ a K. Chyba měřená intervalem byla vypočítána $\mathrm{z}$ rozpětí naměřených hodnot studovaného souboru za pomoci tabelovaných koeficientů Kn pro prríslušný počet pokusů (opakovaných změřených 
hodnot). Výsledky měření budou $\mathrm{v}$ dalším testovacím období ověřovány na větším souboru studentů $s$ rozšířením počtu testů. Předpokládáme, že díky zvětšení souboru testovaných osob a prodloužení působení intervenčního programu se značně zvýší realiabilita našich testů, a tím se i výsledky měření experimentální a kontrolní skupiny budou lišit nad diagnostickou chybu.

$\mathrm{V}$ pilotním měření BMI patřila většina probandek s ohledem na uvedenou kategorizaci $\mathrm{v}$ Tab. 1 do skupiny s normální hmotností. Z výsledků je patrno, že existoval v obou skupinách ještě nenulový počet osob, které už byly zařazeny do sousedních kategorií podváhy, resp. nadváhy. Tato situace nebyla ze statistického hlediska výjimečná, nebot analýzy tohoto typu vykazují gaussovskou závislost, to znamená, že většina výsledků je v pásmu průměrnosti, méně pak v nad a podprůměrných pásmech, absentují extrémy. Ve vstupním měření byla u experimentální skupiny zjištěna průměrná hodnota BMI $21,0 \mathrm{~s}$ průměrnou odchylkou 1,4. Z hlediska třídění osob dle BMI bylo experimentálně potvrzeno, že většina sledovaných probandek patřila mezi osoby s normální hmotností. U kontrolní skupiny byla naměřena průměrná hodnota BMI 21,6 s průměrnou odchylkou 1,6. Tedy i v kontrolní skupině patřila většina probandek k osobám s normální hmotností.

Ve výstupním měření byla u experimentální skupiny zjištěna průměrná hodnota BMI 20,8 s průměrnou odchylkou 1,2. U kontrolní skupiny byla zjištěna výstupní průměrná hodnota BMI 21,6 s průměrnou odchylkou 1,6. Výsledky byly zpracovány jak absolutně, tak i procentuálně, ze základu vstupního měření. Po absolvování pohybového programu poweryogy se u experimentální skupiny průměrná hodnota BMI snížila o 1,3 \%. U kontrolní skupiny nedošlo k žádnému zlepšení, nebot průměrná hodnota BMI se snížila o $0,1 \%$, což byla ze statistického hlediska zanedbatelná změna. Výsledky měření rozdílů vstupního a výstupního měření BMI pro experimentální a kontrolní skupinu jsou uvedeny v Tab. 6 a v Tab. 7.

Tab. 6: Rozdíly vstupního a výstupního měření tělesných parametrů - experimentální skupina

\begin{tabular}{|c|c|c|c|}
\hline & Vstupní data & Výstupní data & Rozdíl \\
\hline Proband č. & BMI & BMI & BMI \\
\hline 1. & 17,8 & 17,7 & $-0,1$ \\
\hline 2. & 22,0 & 21,5 & $-0,5$ \\
\hline 3. & 23,9 & 22,3 & $-1,6$ \\
\hline 4. & 20,7 & 20,5 & $-0,2$ \\
\hline 5. & 18,5 & 18,6 & 0,1 \\
\hline 6. & 20,6 & 20,6 & 0,0 \\
\hline 7. & 21,5 & 21,9 & 0,4 \\
\hline 8. & 22,9 & 22,5 & $-0,4$ \\
\hline 9. & 22,0 & 21,6 & $-0,4$ \\
\hline 10. & 20,4 & 20,4 & 0,0 \\
\hline Průměr & 21,030000000 & 20,76 & $-0,27$ \\
\hline zaokrouhlení & 21,0 & 20,8 & $-0,2$ \\
\hline Medián & 21,1 & 21,1 & $-0,1$ \\
\hline Průměrná odchylka & 1,430000000 & 1,200000000 & \\
\hline zaokrouhlení & 1,4 & 1,2 & \\
\hline & & \% průměrná změna & $-1,283880171$ \\
\hline & & zaokrouhlení & $-1,3 \%$ \\
\hline
\end{tabular}


Tab. 7: Rozdíly vstupního a výstupního měření tělesných parametrů - kontrolní skupina

\begin{tabular}{|c|c|c|c|}
\hline & Vstupní data & Výstupní data & Rozdíl \\
\hline Proband č. & BMI & BMI & BMI \\
\hline 1. & 19,9 & 19,9 & 0,0 \\
\hline 2. & 21,7 & 21,3 & $-0,4$ \\
\hline 3. & 17,8 & 17,8 & 0,0 \\
\hline 4. & 21,1 & 21,1 & 0,0 \\
\hline 5. & 28,7 & 29,2 & 0,5 \\
\hline 6. & 21,2 & 21,2 & 0,0 \\
\hline 7. & 21,1 & 21,1 & 0,0 \\
\hline 8. & 22,0 & 21,6 & $-0,4$ \\
\hline 9. & 21,9 & 21,9 & 0,0 \\
\hline 10. & 20,4 & 20,4 & $\overline{0,0}$ \\
\hline Průměr & 21,58 & 21,55 & $-0,03$ \\
\hline zaokrouhlení & 21,6 & 21,6 & $\mathbf{0 , 0}$ \\
\hline Medián & 21,2 & 21,2 & $\mathbf{0 , 0}$ \\
\hline Průměrná odchylka & 1,596 & 1,61 & \\
\hline zaokrouhlení & 1,6 & 1,6 & \\
\hline & & \% průměrná změna & $-0,139017609$ \\
\hline & & zaokrouhlení & $-0,1 \%$ \\
\hline
\end{tabular}

Protože absolutní rozdíly hodnot BMI byly často menší než odchylky jednotlivých měření, byly všechny zahrnuty do statistické chyby. Distribuce BMI se v experimentální a kontrolní skupině výrazně nezměnily, změny byly zanedbatelné. Je možno konstatovat, že krátkodobý pohybový program neměl dostatečný vliv na BMI $\mathrm{z}$ důvodu malé frekvence pohybových podnětů a vzhledem $\mathrm{k}$ dalším možnostem ovlivnění BMI, zejména změnou způsobu stravování.

Nároky kladené na ženy, tedy i na studentky vysokých škol, v současné společnosti stále stoupají. V mnoha ohledech je od nich očekáván výkon srovnatelný s muži. Respektování zvláštností obou pohlaví se ukazuje důležité jak v tréninku, tak v očekávané pohybové a sportovní výkonnosti. Základním předpokladem pro úspěšnou komplexní intervenci, tedy i pohybovou, je rozpoznání individuálních zvláštností jednotlivce a z nich vyplývajících předpokladů pro daný typ zatížení (Astrand; Rodahl 1986). Ženy mají nižší dispozice pro rychlostně-silový trénink, naopak mají lepší podmínky pro rozvíjení vytrvalosti. Snadněji zvládají činnosti, ve kterých je základem rovnováha. Ve většině př́ípadů lépe „vnímaji“ 'rytmus cvičení. Pohybový program by proto mohl být vhodně spojován s hudbou, při cvičení je vítané akcentování rytmizace pohybu (Novotná; Čechovská; Bunc 2006).

Přikláníme se proto $\mathrm{k}$ názoru, že je potřebné vytvářet speciální nabídku pohybových programů pro studentky vysokých škol v rámci předmětu tělesná výchova, přizpůsobovat obsah ženskému estetickému pohybovému projevu, posilovat nejen tělesnou zdatnost, ale také podněcovat jejich vlastní pohybovou tvořivost a rozvíjet smysl pro krásu.

Pro některé studentky jsou právě jógová cvičení prvním impulsem k uvědomění si svého těla prostřednictvím řízeného pohybu a síly, kterou mají, a k pochopení skutečnosti, že mohou ovlivňovat stav svého organismu a pozitivně ho měnit. Formy jógových cvičení jsou propojeny s řízeným dýcháním vedoucím $\mathrm{k}$ relaxaci, celkovému zklidnění a $\mathrm{k}$ př́padnému odstraňování napětí a stresu. Předpokládáme, že právě studentky vysoké školy, vystavené velkému tlaku a očekávání okolí, budou preferovat takovou pohybovou aktivitu, např́iklad poweryogu, která jim pomůže vyrovnat se s napětím a nároky studia, bude podporovat sebevědomí, posilovat schopnost koncentrace, podněcovat tvořivost a bude přispívat ke zlepšování jejich pocitu životní spokojenosti. 


\section{ZÁVĚRY}

Účinky pohybového programu poweryogy nejsou sice v odborné literatuře dostatečně doloženy, přesto byl praktický efekt pozitivního ovlivnění pohybového projevu cvičenek zjevný. Jednotlivé části intervenčního programu měly vliv na zlepšení úrovně statické rovnováhy, vedly k estetickému provádění pohybů a k osvojování si nových dovedností. Společné prožívání cvičení vedlo ke vstřícné atmosfére ve skupině, ke vzájemné podpoře při překonávání obtížnosti jednotlivých cviků a k vytváření specifického mikroklimatu sounáležitosti.

Přínos programu bude dále komplexně ověřován dalšími metodami výzkumu u většího počtu měřených osob. Očekáváme, že tím dojde k signifikantnímu zvýšení reliability našeho měření. Cílem vědeckého výzkumu, jehož je předložené pilotní měření součástí, je dokázat pozitivní účinky poweryogy na lidské tělo a zkvalitnění aktivního stylu života. Již z pilotního měření je zřejmé zlepšení statické rovnováhy. Zvýšením počtu měřených osob a prodloužením délky pohybového programu budeme schopni přesněji zjistit změny BMI. Přidáním dalších měření tělesných parametrů a pohybových dovedností by pak bylo možné podpořit význam poweryogy pro zdravý a aktivní způsob života. Řada odborníků si je vědoma pozitivních účinků poweryogy. Naším cílem bude tyto účinky vědecky ověřit, a tím zvýšit důležitost a častější výskyt programu poweryogy v hodinách vysokoškolské tělesné výchovy. Výsledky pilotního výzkumu budou využity pro úpravu pohybového programu. Předpokládáme, že aplikace intervenčního programu poweryogy přinese cvičenkám nové podněty pro změnu způsobu života a že jim pravidelná pohybová aktivita pomůže překonávat nároky studijní zátěže.

\section{Literatura}

ASTRAND, P. O.; RODAHL, K. Textbook of Work Physiology. New York : McGraw Hill, 1986.

BAPTISTE, B. Poweryoga. New York : Omega, 1988.

BLAHUŠ, P. K systémovému pojetí statistických metod v metodologii empirického výzkumu chování. Praha : Karolinum, 1996.

BLAHUŠ, P.; MĚKOTA, K. Motorické testy v tělesné výchově. Praha : SNP, 1983.

DOLEŽAJOVÁ, L.; LEDNICKÝ, A. Rozvoj koordinačních schopností. Bratislava : SVTVŠ, 2002.

FIALOVÁ, L. Moderní body image. Jak se vyrovnat s kultem štíhlého těla. Praha : Grada, 2006.

HOWE, T. E.; ROCHESTER, L.; NEIL, F.; SKELTON, D. A.; BALLINGER, C. Exercise for improving balance in older people. Cochrane database of systematic reviews, 2011.

KREJČÍ, M. Jóga v praxi pedagoga. České Budějovice : PF JU, 1995.

KREJČÍK, V. Zdravý život s powerjógou. Praha : Ikar, 2005.

NEUMAN, J. Cvičení a testy obratnosti, vytrvalosti a síly. Praha : Portál, 2003.

NOVOTNÁ, V.; ČECHOVSKÁ, I.; BUNC, V. Fit programy pro ženy. Praha : Grada Publishing, 2006.

PAŘÍZKOVÁ, J. Složení těla, metody měření a využití ve výzkumu a lékařské praxi. Medicina Sportiva Bohemica et Slovaca, 1998, č. 7.

STREŠKOVÁ, E. Rozvoj koordinačných schopností ako predpoklad skvalitnenia technickej prípravy v športe. Zborník prednášok zo vzdelávacích aktivit národného športového centra. Bratislava, 2004, s. 234. STREŠKOVÁ, E. a kol. Úroveň rovnováhových schopností a vestibulárneho analyzátora v gymnastických, tanečných a úpolových športoch. Zborník prác z výsledkov grantovej úlohy VEGA č. 1/0413/08. Bratislava : Univerzita Komenského, FTVŠ, 2010, s. 15.

THOMAS, J. R.; NELSON, J. K. Research methods in physical activity. 3.vyd. Champaign : Human Kinetics, 1996. ISBN 0-7360-4419-1.

THOMLEY, B. S.; RAY, S. H.; CHA, S. S.; BAUER, B. A. Effects of a brief, comprehensive, yoga-based program on quality of life and biometric measures in an employee population: a pilot study. Explore, New York, 7 (1), 27-29, 2011. 